Page $139-158$

\title{
TRANSACTION COST ON THE IMPLEMENTATION OF E-INVOICES IN MICRO AND SMALL ENTERPRISES
}

\author{
Clara Palupi', Darwanto ${ }^{2}$ \\ Universitas Diponegoro \\ 'palupiclara@gmail.com; ²darwanto@live.undip.ac.id
}

\begin{abstract}
E-invoice is one of the tax administration modernization program created to reduce the tax compliance costs in order to improve the tax compliance. This paper aims to prove that e-invoice as a form of institutional change can actually change or lower the tax compliance costs. Using a qualitative approach case study method and supported by evidence of calculation of the cost of compliance. The results showed that e-invoice cannot directly reduce the tax compliance costs, because e-invoice is a new program and the taxpayers bear big the amount of time cost for the process of adjustment (adapt). Tax compliance costs will increase temporarily during the adaptation process; the total compliance cost in the six months after the e-invoice increased 3.4 percent from the six months before. Then, the results of tax compliance costs estimated at one year after the e-invoice applied showed that the compliance costs decrease 31 percent from the cost of compliance without e-invoice.
\end{abstract}

Keywords: tax compliance costs, e-invoice, corporate taxpayers

\begin{abstract}
ABSTRAK
E-faktur merupakan salah satu program modernisasi administrasi pajak yang dibentuk untuk menurunkan biaya kepatuhan. Makalah ini bertujuan untuk membuktikan bahwa e-faktur sebagai bentuk perubahan kelembagaan bisa mengubah atau menurunkan biaya kepatuhan pajak. Menggunakan analisis kualitatif dengan metode studi kasus dan didukung dengan perhitungan dari biaya kepatuhan pajak. Hasil menunjukkan bahwa e-faktur tidak bisa mengurangi biaya kepatuhan pajak secara langsung, karena e-faktur merupakan program yang relatif baru, wajib pajak mengeluarkan biaya waktu yang besar pada proses pemahaman (adaptasi). Biaya kepatuhan pajak akan terus bertambah selama proses proses adaptasi, total dari biaya kepatuhan selama 6 bulan setelah e-faktur bertambah sebesar 3,4 persen dari enam bulan sebelumnya. Lebih lanjut, hasil dari estimasi biaya kepatuhan pajak selama I tahun setelah e-faktur menunjukan penurunan sebesar 3 I persen dari biaya kepatuhan pajak sebelum e-faktur.
\end{abstract}

Kata Kunci: biaya kepatuhan pajak, e-faktur, wajib pajak badan

Received: January 3, 20I7; Revised: February 5, 20I7; Approved: February 20, 2017 
Transaction Cost on The Implementation....

Clara Palupi, Darwanto

\section{INTRODUCTION}

The total tax revenue is the largest in the state revenue. When compared with the total amount of state revenue, the tax revenue in 2012 to 2016 is always over 70 percent annually while the non-tax revenue is only between 15 percent to 27 percent and the grant is less than one percent every year (Memorandum of Finance Budget $2012,2014,2015)$. As the most reliable state revenue, tax revenues are required to improve in line with the increasing financing needs of the state. In order to increase the tax revenues, the government has made a great step that is the reform of taxation. The first reform is conducted by changing the tax collection system from the Official Assessment System (OAS) into Self-Assessment System (SAS) with the aim of encouraging the people's voluntary compliance on taxes.

SAS has been running for 33 years, but it has not been able to optimize the tax compliance. The tax coverage ratio rate (ratio between the levied tax realization and the actual potential tax) is still low. Fuad Rahmany in Gumiwang (2014) as the Director General of Taxes stated that Tax coverage in Indonesia is only about 50 percent of the total actually existing in the Indonesian economy. SAS is not optimal yet because it increases the transaction costs in the taxation borne by the taxpayers or the tax compliance costs (compliance cost). Sandford (1990) in Mansor and Hanefah (2008) stated that SAS is proven to increase the compliance cost because it transfer all responsibility for taxation affairs to be conducted independently by the taxpayer.

The increased compliance costs would burden the non-production costs of the taxpayer especially the micro and small enterprises (MSEs). Mansor and Hanefah (2008) stated that the application of SAS would increase the burden of the taxpayer in the form of compliance costs, which may not be a problem for the big companies but may pose a heavy burden for the small and medium enterprises. The government continues the tax reform with tax reform Volume I and II, one of which is creating the tax administration system based on technology with the aim of reducing the compliance cost borne by the taxpayer, one of which is the e-invoice. E-invoice is an invoicing application of online tax that aims to reduce the compliance cost of business enterprise taxpayers (Directorate General of Taxation, 20I2). In the perspective of institutional economics, e-invoice can be categorized as one form of institutional changes such as the use of technology that is deliberately created by the agency / 
authority (in this case the Directorate General of Taxes) that aims to transform or reduce the transaction costs (Yustika, 20I3).

One of the factors that affect the high-low level of tax compliance is tax compliance costs (UN-DESA, 20I4). Cedric Sandford in Prasetyo (2008) mentioned that the compliance costs should not be burdensome and inhibit the taxpayer to pay the tax. As mentioned in the principles of taxation by Adam Smith, the tax collection must comply with the principle of efficiency. Efficient means that the tax collections from the taxpayer should be done with minimal cost, so the cost to be incurred by the taxpayer is not higher than the taxes paid. Furthermore, Sanford classified three types of costs in paying taxes. First, the sacrifice of income is the cost of sacrifice of the individual to use the income or property to pay the tax. Second, the distortion cost is the cost incurred by the taxpayers because of the change process and production factors related to the changes in the pattern of economic behavior for their taxes. Third, the running cost is the costs that are not incurred by the taxpayers if there is no tax system, including: (I) the administrative costs, which is the cost of implementation of the national tax system by the government; (2) the compliance costs, which is the cost of meeting tax obligations by the taxpayers.

Organization for Economic Co-operation and Development (OECD) define tax compliance as a measure of the extent to which taxpayers comply (or not comply) the tax rules of the country, for example by reporting income, resubmit the report, and pay taxes on time. According to Norman in Kiryanto (2000), tax compliance is a situation when : (I). taxpayers understand or trying to understand all the provisions of the law of taxation; (2). complete and clearly defined the tax forms; (3) calculate the amount of taxes payable correctly; and 4). pay the taxes payable on time.

Mansor and Hanefah (2008) stated that the compliance cost is the cost associated with following the requirements of the tax rules including the cost for preparing or filing the tax returns on time in accordance with the tax laws prevailing in a state. Smulders and Stiglingh (2008) mentioned that the descriptions and definitions of compliance cost are generally included in the following elements: (a) The value of the time spent by the owner, the manager, staff and others of a business to understand 
Transaction Cost on The Implementation....

Clara Palupi, Darwanto

and implement the taxation; (b) The registration cost, the cost for complaints and other costs associated with preparing the tax return (form of tax/SPT); (c) The costs to pay the tax experts, consultants, lawyers and accountants; (d) The costs related to the unplanned things related to the tax payment such as telephone, transport, and others.

Furthermore, Rahayu in Prasetyo (2008) defined the tax compliance costs as the costs to process the tax payments incurred by the taxpayer out of the tax payable. These costs are calculated starting from planning the tax, receiving the appeals, up to paying off the tax payable. Furthermore, Rahayu grouped two forms of tax compliance costs as follows: the actual cash outlay that is defined as all expenses in cash incurred by the taxpayers to make the tax obligations, and the opportunity cost of time that is defined as the value of time spent by the taxpayers to make the tax obligations, which are then converted to rupiah value.

Based on the recent description, this study empirically measures and analyzes the transaction costs for the change of Official Assessment System (OAS) into Self-Assessment System (SAS). This research focus on how e-invoice can change or reduce the tax compliance cost of the taxpayers from the micro and small enterprises in KPP Pratama Semarang Candisari. KPP Pratama Semarang Candisari was choosen because of there is no different rules and policies from another KPP in the Indonesia. The finding of this study are hoped to give some policies, suggestion, and evaluation for government, also gives a perspective about SAS and the tax compliance cost for the MSEs and society in general.

There are several previous studies to be a reference for this study. Susila and Pope $(2010)$ conducted a study of a compliance costs for large companies in Indonesia titled The Magnitude and the Features of Tax Compliance Costs of Large Companies In Indonesia. Klun (2009) compared the tax compliance costs of the tax year 2000 with tax compliance costs in fiscal years 2007 and 2008, after the tax reform in the form of pre-filed return (checking or refilling mail notification at tax or return of personal income tax by the taxpayer in the amount of taxes which has been counted by the government) and e-filing, such a notification letter is filled then reported electronically or online. Ibrahim (20/4) estimating the cost of compliance, in the form of tax compliance costs of personal income tax and determine the effect of e-filing on the 
time cost of the tax compliance costs in Malaysia. Mansor et al (2009) conducted a different test (t-test) which analyze the difference between the manual tax payment and online tax payment. Smulders dan Stiglingh (2008) analyzed the cost that dominate the tax compliance costs for small businesses. Hansford and Hasseldine (2012) analyzed the average amount of tax compliance costs on small enterprises in the UK. Evans et.al (2013) analyze the increase of the tax compliance costs in Australia from 1995 and 2012. Sapiei et.al (2014) analyzed the impact of the high of tax compliance cost (compliance costs) in a certain company.

Based on the observation of the literature, there has been no research that compare the transation costs as a result of institutional change of the taxation in Indonesia, before and after the SAS system. In terms of location research, there has been no similar study conducted in the Semarang City, especially in KPP Candisari Semarang. In addition, the other studies that conducted in Indonesia, have not covers micro enterprises as the research object, only small businesses and large businesses. As in Susila and Pope (2010), which examined only on large enterprises in Indonesia.

\section{METHOD}

The object of this research is the tax compliance costs in the case of institutional changes in the form of technical changes of the calculation activity to the tax reporting on the implementation of E-invoices. Informants in this research are the three types of key persons those are one academician, one tax officer, and key persons of taxpayers, who are the owners or employees of small micro enterprises that do the taxation. Definition and criteria for micro and small businesses used are in accordance with the Acts No. 20 of 2008 on Micro, Small and Medium Enterprises. The data collection is conducted by observation and in-depth interviews.

This research is conducted with a qualitative approach of case study method, which is a qualitative approach that explores the real life in the form of a case or multiple cases through detailed and in-depth data collection involving various information so that the information can be conveyed through a description of the case (Creswell, 2009). The case study method is used to find changes in the components of tax compliance costs in the calculation procedure until the VAT reporting before and after the adoption of e-invoice, as well as the opinion of the taxpayer on the role of e- 
Transaction Cost on The Implementation....

Clara Palupi, Darwanto

invoice in reducing the tax compliance costs. Then, to give evidence or proof that the application of e-invoice can actually change the tax compliance costs, the amount of tax compliance costs before and after the adoption of e-invoice is calculated and the different test of Wilcoxon is performed.

Triangulation method is used as a validity strategy of the research, in which the authors compare or view the suitability of observations conducted on STO Semarang Candisari with the interview result, and compare the results of interviews with key persons of taxpayers with the results of interviews conducted with key persons of tax officials and key persons of academics. The authors also make a comparison between the results of interviews with some of the documents related to e-invoice, published by the General Directorate of Taxation.

VAT compliance costs are the cost and time spent by the taxpayers in order to comply with the VAT regulations beyond the amount of VAT paid. Such costs consist of direct money cost and time cost. Direct money cost or direct cost is the value of money that must be spent by the taxpayer for making payment obligations and taxation rights (Rosdiana \& Tarigan, 2005). These costs consist of: (a) The cost for buying or printing forms of tax invoices; (b) The cost for transportation to the Bank or Post Office; (c) The cost for transportation to the KPP; (d) The cost for printing and doubling the SPT.

Time cost is the cost in the form of time required by one taxpayer to carry out the obligations of taxpayers and taxation rights (Rosdiana \& Tarigan, 2005). Time cost calculation is done by quantifying the time (in hours) in the form of money, by multiplying the time spent to perform an obligation and taxation rights to the average net salary in the corporate tax staff counts per hour (Eragbhe and Modugu, 2014).

Different test is conducted to find the real difference between the amount of tax compliance costs before and after the adoption of e-invoice. Wilcoxon test is a test that uses the difference of relevant direction signs to determine whether there is a significant difference between pairs of data from one or two samples interrelated or not. 


\section{RESULTS AND DISCUSSION}

Based on the interviews with the key persons of taxpayers, it is known that before the e-invoice the taxpayers pass through the VAT collection procedures, in which the taxpayers make the tax invoice as the evidence of tax levies made by every business entity delivering the taxable goods or rendering of taxable services. The tax invoice is created manually by filling out the form of tax invoice obtained by buying or downloading from the internet. After the process of making the tax invoice, based on the tax invoice recapitulation, the taxpayers then calculate the amount of VAT that should be paid based on the difference between the output tax and the input tax. Furthermore, the taxpayers make the tax payment at a bank or post office by bringing SSP (Tax Payment) pre-filled. After the payment, the taxpayers will receive a proof of payment that will then be used as an attachment when reporting. The reporting process is done by bringing the e-SPT that has been filled before. The e-SPT filling can be done at the same time the taxpayers in the tax return to fill the SSP because the taxpayers must include the invoice numbers. E-SPT Period of VAT is reported in print and soft file in the form of CSV file, accompanied by the third sheet of SSP and also the proof of payment.

In the process of calculation until the reporting of SPT VAT without e-invoice, there are the tax compliance costs whether in the form of direct costs or time cost incurred by the taxpayers. These costs are as follows:

Table I

Tax Compliance Costs on Process of Calculating, Depositing, and Reporting SPT Period of VAT before E-invoices

\begin{tabular}{clll}
\hline No & \multicolumn{1}{c}{ Stages } & Direct cost incurred & Time cost incurred \\
\hline I. & Tax collection & $\begin{array}{l}\text { Cost for buying or } \\
\text { printing form } \\
\text { of tax invoice }\end{array}$ & Time spent for preparing \\
2. & - Making tax invoice & No direct cost & Tax invoice \\
3. & Tax deposit & Transport cost to & Tank or Post Office \\
& & Transport cost to KPP & Time spent for waiting in line \\
4. & Tax report & Cost for printing and doubling SPT & Time spent for filling SPT \\
\hline
\end{tabular}

Source: Data processed, 2016 
Transaction Cost on The Implementation....

Clara Palupi, Darwanto

The Directorate General of Taxation obliges the taxpayers across Java and Bali to use e-invoice in July 2015. To be able to use e-invoice application, the taxpayer must first carry out the registration process, so in this research the authors also include the registration process of e-invoices in the components of transaction costs calculated. Based on the interviews, the taxpayers must come to the tax office as many as twice or more to take care of the registration. One of them, Indah, the commissioner CV. Aditya Wiguna, gave the following statement:

"Yeah, I have to go back and forth until more than four times, it seems because there is a document missing; besides I have to wait in line so long because it is very crowded".

Furthermore, during the transition from the use of manual tax invoices into e-invoices there is a change of process. This change requires the taxpayers to study and understand the procedures for the use of e-invoices. Although prior to July 2015 KPP Semarang Candisari has conducted mass socialization three times, a few key persons still take a long time to understand e-invoices. One of them is Noer Hidayat, Manager of PT.Tridaya Mandiri, who stated that:

"The size is not hours, it seems that until two weeks I have understood all"

The same thing is felt by Dewi, Director of CV. Ben Resik Solution, who gave the following statement:

"Approximately it takes four days that I have been looking for the consultation and the AR at the Internet by myself ".

Furthermore, after the e-invoice is used, the tax invoice is no longer issued manually but online. The taxpayers who conduct the transactions would include the transaction data and then upload the invoice, then the tax directorate general server will approve (confirm the tax invoice). The same thing as before using the e-invoice, after the process of tax collection, the calculated tax is calculated based on the tax invoices and then made a deposit. The taxpayers will fill the SSP and pay the tax payable to the bank / post office. Then, in the process of filling the e-SPT to the report, the taxpayers no longer need to fill in the number of tax invoices manually, but it has been automatically connect from e-invoice so that the filling time of e-SPT becomes shorter. 
In the procedure of calculation until reporting the VAT after the adoption of einvoices, including the registration process and adjustment to e-invoice, the taxpayers bear the tax compliance cost as follows :

Table 2

Tax Compliance Costs on Process of Calculating, Depositing, and Reporting SPT Period of VAT after E-invoices

\begin{tabular}{clll}
\hline No & Stages & Direct Costs incurred & Time Costs incurred \\
\hline I. $\begin{array}{l}\text { Registration of E- } \\
\text { invoices }\end{array}$ & $\begin{array}{l}\text { I. Transport cost to KPP } \\
\text { 2. Cost for printing the } \\
\text { equirements }\end{array}$ & $\begin{array}{l}\text { I.Time spent for waiting } \\
\text { in line at KPP }\end{array}$ \\
& No direct costs & $\begin{array}{l}\text { 2.Time spent for understanding } \\
\text { the e-invoices } \\
\text { Time spent for preparing } \\
\text { the tax invoices }\end{array}$ \\
$\begin{array}{llll}\text { 2. Tax Collection } \\
-\quad \text { Make tax }\end{array}$ & No direct costs & $\begin{array}{l}\text { Time spent } \\
\text { for filling SSP }\end{array}$ \\
3. Tax Calculation & Transport cost to Bank & $\begin{array}{l}\text { Time spent for } \\
\text { waiting in line }\end{array}$ \\
4. Tax Payment & or Post Office & I. Time spent for filling the SPT \\
5. Tax Reporting & $\begin{array}{l}\text { I. Transport cost to KPP } \\
\text { 2. Cost for printing and doubling } \\
\text { the SPT }\end{array}$ & 2. Time spent at KPP \\
\hline
\end{tabular}

Source: Data, processed

*Registration of E-Invoices only occurs once in July 2015

The implementation of e-invoices eliminates the direct cost for buying the form of tax invoices and lowers the time cost spent for making the tax invoices and filling the e-SPT. However, in the process of transition of the ordinary tax invoice into e-invoices, the new tax compliance costs appear, which are the direct costs for the registration process of e-invoices in the form of transportation costs and the cost for printing the document of registration requirements and time costs such as the cost of time spent at KPP and the cost of time spent for understanding / learning the e-invoices so the taxpayers can operate the application of e-invoices independently.

Directorate General of Taxation (2012) mentioned that the benefits of einvoices felt by the taxpayers is to provide a sense of comfort to the taxpayers during the work process to save the tax invoice. By the existence of these e-invoices, the taxpayers will no longer require a tax invoice with wet signatures. Tax invoice is already a $\mathrm{QR}$ code (digital signature). The taxpayer is not required to print a tax 
Transaction Cost on The Implementation....

Clara Palupi, Darwanto

invoice. Moreover, the electronic notification letter (e-SPT) has been integrated with the e-invoice application. The use of e-invoices does not only bring benefits to the taxpayer, but it is also felt by the Directorate General of Taxation. For the Directorate General of Taxation, the e-invoice application makes them easier to conduct the surveillance through a validation process of Output Tax - Input Tax (PK-PM), which is supported by the data in the form of invoices of each mandatory state and minimize the document storage process. E-invoices also simplify and speed up the service, and minimize the misuse of tax invoice by a fictitious company.

Panca Mukti Wibowo, as an academic, stated that modern administrative system, especially e-invoices, provides convenience for both parties either the taxpayers or the tax authorities (tax officials). Here is his direct statement:

"Yes, the goal is to provide convenience for the taxpayers and the tax authorities. Facilitating the taxpayer means having to lower its compliance cost, facilitating the tax authorities means having to lower the administrative cost. It gives a very big impact to the taxpayers. The manual invoice should have the wet signature, now not anymore. Once it should be manually written, now it can be typed directly and the data will be stored neatly. Once if you want to make a report, you should write in SPT one by one, now it has become a unity that has the same e-SPT so it directly connect automatically to e-SPT and there will be recaps of input tax and output tax then there will be found the difference of the tax payable. Yes, it definitely reduces the compliance cost because it does not need to wear a form of paper invoices again, it reduces the time especially when the taxpayers are already reporting the e-SPT online (e-filing), there will be a lot of advantages. For example, tomorrow is the final report dated 20, the tax offices are closed at 4 but with e-filling, the taxpayers still can submit up to 12 o'clock at night. "

E-invoice is proven to reduce the tax compliance costs by eliminating the direct costs for buying or printing the tax invoices and also lowering the cost of time. The previous statement was supported by the statement of key persons above and supported by the explanation of the publication of the Directorate General of Taxation, and based on the description in the calculation process to the reporting of SPT Period of VAT after the e-invoices. However, it should be discussed whether the evidence is equal to what is perceived by the taxpayers. Therefore, the interview will clarify the role of e-invoices perceived by the key persons of the taxpayers in order to 
reduce the tax compliance costs that they incur.

As a result, nine of the 32 key persons of the taxpayers stated that the einvoice properly reduce the tax compliance costs because it eliminates the cost of buying the form tax invoices. The statement is delivered by Dwi, one of administrative staffs of PT. Dewi Wahana Jaya:

"Yeah, it reduces for not buying anymore form of invoices, but the amount of paper for the report is still the same."

A similar statement is delivered by Bambang, an accountant of CV. Trias Hutama:

"Yeah, it reduces the cost and time for not requiring to buy another form of invoices to make the invoices."

Some key persons feel that it is true that e-invoice reduces the compliance costs. However, there are other problems that make them not feel the cost reduction. The statements include the one from Juli, an accountant of PT.Satria Mas Karya Tama, as follows:

"Yeah, it reduces the cost for not buying the form of invoices anymore but for me, the cost for transportation and time to the tax office is greater because the e-invoice application is often problematic".

Indah Puspita Sari, CV. Aditya Wiguna, gave a statement as follows:

"It slightly reduces the time cost; the time to prepare a tax invoice for the reports becomes shorter as long as the internet connection is good. If it is not good, it will be the same."

The majority of key persons consider that there is no difference in the costs that they feel after there is e-invoice. One of them, Karina, the director of CV. Carine, gave a statement as follows:

"I think the costs are similar, because we should still have to print the e-SPT and still have to come to the KPP."

Supri, the director of CV. Danu Sakti, stated that:

"I think it does not reduce any cost, it is just the same before and after the e-invoice. Even after the e-invoices we should often go to the office if there is a trouble at the application."

Based on the statements given by the key persons during the interview, it is known that the majority of the key persons actually realize that e-invoices reduce their 
Transaction Cost on The Implementation....

Clara Palupi, Darwanto

tax compliance costs by eliminating the cost of buying the form of invoice or printing the invoice forms. However, the cost reduction is smaller than the loss they feel to adapt to the e-invoice system. The majority of key persons complain of the new costs they should spend to be able to access the internet. The key persons also complain the weakness of e-invoice application that is often problematic (server error or down).

The implementation of e-invoices change the components of tax compliance costs with when first used at the stage of registration, and the adjustment of the taxpayer to be able to use e-invoice emerges the new costs those are the cost for transportation to KPP, the cost for printing the document of requirement, the time cost spent for waiting in line at KPP and the time cost spent for understanding the e-invoices. However, the use of einvoices also eliminates the cost for buying or printing the form of tax invoices and lowers the time cost for making a tax invoice and filling the SPT. Components of tax compliance costs when e-invoice is first used is shown in Table 3.

Table 3

Components of Compliance Costs of VAT in July 2015

\begin{tabular}{|c|c|c|}
\hline Items & Direct Costs & Time Costs \\
\hline Registration of E-invoice & $\begin{array}{l}\text { 1.Transport cost to KPP } \\
\text { 2. Cost for printing the } \\
\text { document of requirement }\end{array}$ & $\begin{array}{l}\text { I. Time spent for waiting in line } \\
\text { at KPP } \\
\text { 2. Time spent for } \\
\text { understanding the e-invoices }\end{array}$ \\
\hline $\begin{array}{l}\text { Process of collection, } \\
\text { calculation, }\end{array}$ & $\begin{array}{l}\text { I.Transport cost to Bank or } \\
\text { Post Office }\end{array}$ & $\begin{array}{l}\text { I. Time spent for preparing } \\
\text { the tax invoices (fewer than }\end{array}$ \\
\hline $\begin{array}{l}\text { payment, and } \\
\text { reporting the SPT }\end{array}$ & 2.Transport cost to KPP & before the e-invoices) \\
\hline Period of & 3. Cost for printing and doubling & 2. Time spent for filling SSP \\
\hline \multirow[t]{3}{*}{ VAT } & SPT & $\begin{array}{l}\text { 3.Time spent for waiting in line } \\
\text { at bank/post office }\end{array}$ \\
\hline & & $\begin{array}{l}\text { 4.Time spent for filling SPT } \\
\text { (fewer than before e-invoices) }\end{array}$ \\
\hline & & $\begin{array}{l}\text { 5. Time spent for waiting in line } \\
\text { at Tax office }\end{array}$ \\
\hline
\end{tabular}

Source: Data processed, 2016

To see the amount of change in the component of compliance costs before and after the adoption of e-invoices, the calculation of VAT compliance costs of the tax year 2015 is conducted that then compare the average over six months before and six months after the e-invoice. 
Table 4

Changes in VAT Tax Compliance Costs Before and After E-invoices in the Fiscal Year 20 I5 (Rupiah)

\begin{tabular}{ccc}
\hline Average of 6 months before & Average of 6 months after & Average of changes \\
\hline E-Invoice & E-Invoice & \\
$173.618,6898$ & $179.600,5044$ & (Increase) \\
& & $5.9818,1(3.4 \%)$ \\
\hline
\end{tabular}

Source : Data processed, 2016

The number of tax compliance costs on average at six months after the adoption of e-invoice increases slightly from an average of six months before the application of e-invoice, which amounted Rp. 5.9818,I. The reason is because the decrease in the number of direct costs due to the missing costs for printing or buying the form of tax invoice is less than the increase in the amount of time costs incurred in the process of registration of e-invoices. Table 5 illustrates the average number of changes in direct costs and time costs within six months before and six months after the implementation of e-invoices.

Table 5

Average of Total Change of VAT Tax Compliance Costs tax year 2015 (Rupiah)

\begin{tabular}{|c|c|c|c|c|c|}
\hline $\begin{array}{l}\text { Average } \\
\text { Direct }\end{array}$ & $\begin{array}{l}\text { Average } \\
\text { Direct }\end{array}$ & $\begin{array}{l}\text { Average } \\
\text { Time }\end{array}$ & $\begin{array}{l}\text { Average } \\
\text { Time }\end{array}$ & Average & Average \\
\hline $\begin{array}{l}\text { Costs } \\
\text { Before }\end{array}$ & $\begin{array}{l}\text { Costs } \\
\text { After }\end{array}$ & $\begin{array}{l}\text { Costs } \\
\text { Before }\end{array}$ & $\begin{array}{l}\text { Costs } \\
\text { After }\end{array}$ & $\begin{array}{l}\text { of change } \\
\text { of direct }\end{array}$ & $\begin{array}{l}\text { of change } \\
\text { of time costs }\end{array}$ \\
\hline E-invoice & E-invoice & E-invoice & E-invoice & & \\
\hline
\end{tabular}

\begin{tabular}{llllll}
$68.159,7$ & $46.902,2$ & $105.458,9$ & $132.698,2$ & $\begin{array}{l}\text { Decrease } \\
21.257,4\end{array}$ & $\begin{array}{l}\text { Increase } \\
27.239,2\end{array}$ \\
\hline
\end{tabular}

Source: Data processed, 2016

The time costs increase by Rp 27.239,2 while the direct costs only decrease by Rp 21.275.4. The time costs incurred in the process of registration of e-invoice is high. The high cost of the time is because at the process of registration the taxpayers need some time to come to the tax office and spend hours to wait in line and also the time to learn about e-invoice, which takes several days. Lowering the cost of time to make a tax invoice and fill the SPT only decreases in unit time of minutes, so although the registration process only occurred in July 2015, the amount of increase in the cost of time is still greater than the total amount of reduction in the direct costs over six months of adoption of e-invoices. Overall, during six months after the e-invoice is 
Transaction Cost on The Implementation....

Clara Palupi, Darwanto

used, the average amount of tax compliance costs is slightly more than six months before the adoption of e-invoices.

Furthermore, to determine whether there are significant differences between the data in compliance costs of six months before and six months after the e-invoice is used, the different test is used on both the data. Different test performed is nonparametric different test of Wilcoxon Signed Rank which result is known that the value of the $t$ count statistic is 164 . This value is greater than the value of the $t$ table statistic with the total number of observation is 1.69 , so Ho is accepted, which means there is no real difference in the compliance costs of six months before and six months after the e-invoice. Based on the probability value, the value of Asymp. Sig is $0.06 \mathrm{I}$ greater than the significance level of 0.05 then $\mathrm{Ho}_{\mathrm{o}}$ is accepted, there are no significant differences in tax compliance costs before and after the use of e-invoices.

\section{Table 6}

Wilcoxon Signed Ranks Test Results on VAT Tax Compliance Costs Six Months Before E-invoice and Six Months After E-invoice

\begin{tabular}{cccccc}
\hline & Ranks & & & Statistic Test & \\
& & Mean Rank & Sum of Ranks & $Z$ & $-1.870^{\mathrm{b}}$ \\
\hline Negative ranks & $\left.2\right|^{\mathrm{a}}$ & 17.33 & 364.00 & Asymp. Sig (2-tailed) & $.06 \mathrm{I}$ \\
Positive ranks & $\mathrm{I}^{\mathrm{b}}$ & $14.9 \mathrm{I}$ & 164.00 & & \\
Ties & $0 \mathrm{c}$ & & & & \\
Total & $3 \mathrm{I}$ & & & & \\
\hline
\end{tabular}

Source: Data processed, 2016

After July 2016, the use of e-invoices will eliminate the direct costs on VAT compliance costs those are the costs for buying or printing the tax invoice and also lower the cost of time for making the tax invoice and filling the SPT. So the total tax compliance costs component changed as follows:

Table 7

Components of Tax Compliance Cost After E-invoices

\begin{tabular}{ll}
\hline \multicolumn{1}{c}{ Direct Costs } & Time Costs \\
\hline (I) $\begin{array}{l}\text { Transport cost to } \\
\text { Bank or Post Office }\end{array}$ & (I) Time spent for preparing the tax invoice \\
(decreased from before e-invoice) \\
(2) Transport cost to & (2) Time spent for filling SSP \\
KPP & (3) Time spent for waiting in line at \\
(3) Costs for printing and & bank/post office \\
& (4) Time spent for filling SPT \\
& (decreased from before e-invoice) \\
& (5) Time spent for waiting in line at tax office
\end{tabular}

Source: Data processed, 2016 
To see how big the reduction in VAT compliance costs for changing the amount of tax compliance costs, in this section we describe the results of the estimated total tax compliance costs in the years before and after the einvoice. According to table 9, tax compliance costs are calculated to estimate the cost of tax compliance for one year after the e-invoice by assuming that the components of costs incurred during the registration process and adapt to the e-invoice (time cost for understanding or learning the e-invoice) is already lost. The result of the calculation of estimated tax compliance costs is shown in the Table 8.

\section{Table 8}

\section{Total Estimation of Tax Compliance Costs One Year Before and After E-} Invoices (Rupiah)

\begin{tabular}{cccc}
\hline $\begin{array}{c}\text { Before E-Invoice } \\
\text { (One Year Estimation) }\end{array}$ & $\begin{array}{c}\text { After E-Invoice } \\
\text { (One Year Estimation) }\end{array}$ & $\begin{array}{c}\text { Average of reduction of } \\
\text { compliance costs }\end{array}$ \\
\hline $341.190,0005$ & $234.241,5927$ & $106.948,4078$ & $(31 \%)$
\end{tabular}

Source: Data processed, 2016

The average difference in total estimation of tax compliance costs for one year before and after the e-invoice is the tax compliance costs reduced an average of Rp 106.948,4078. The decrease in the compliance cost is due to the missing of direct costs. The direct costs in question is the cost for printing or buying the form of invoices and the decrease of the time cost spent for making the tax invoice and filling the SPT.

Different test is also performed to see whether there is a real difference on the two tax compliance cost data one year before and after the e-invoice. The results of Signed-Rank Wilcoxon different test showed that based on the figures, the value of $t$ count statistic is 8 greater than the value of $t$ table statistic that is 1.69. So, Ho is accepted, which means there is no significant difference in the compliance cost in one year before and one year after the e-invoice. 
Transaction Cost on The Implementation....

Clara Palupi, Darwanto

Table 9

Results of Signed Rank Wilcoxon Test on Estimation of Tax Compliance Costs One Year before E-Invoice and One Year After E-Invoice

\begin{tabular}{cccccc}
\hline & Ranks & & & \multicolumn{2}{c}{ Statistic Test } \\
& & Mean Rank & Sum of Ranks & Z & $-4.703^{\mathrm{b}}$ \\
\hline Negative ranks & $30^{\mathrm{a}}$ & 16.27 & 488.00 & Asymp. Sig (2-tailed) & .000 \\
Positive ranks & $\mathrm{I}^{\mathrm{b}}$ & 8.00 & 8.00 & & \\
Ties & $\mathrm{I}^{\mathrm{c}}$ & & & & \\
Total & 32 & & & & \\
\hline
\end{tabular}

Source: Data processed, 2016

The calculations show that the probability figure of Asymp. Sig is 0.00 , this figure is less than the significance level of 0.05 . Based on these results, a decision that can be taken is Ho is rejected, which means that there is a real difference between the tax compliance costs one year before and one year after the use of einvoices.

The results shows that e-invoicing is not removing any taxpayers activity. E-invoicing is only shorten the time in the activity for invoicing and charging tax notification letter (SPT). Nevertheless, e-invoicing can lowered the estimated VAT compliance costs within one year, amounted to $31 \%$ of the compliance cost without e-invoicing. This is in line with the previous research from Klun (2009), who found that the institutional change is almost similar to einvoice in the form of tax reform in the form of pre-filled program and e-filing for personal taxpayers in Slovenia that is able to reduce the tax compliance costs by 73 percent. The huge change happens since the comparison is made in 2007 and 2008 of the fiscal years when the program was introduced and applies total compliance costs with the 2000 tax year. The research of Mansor et al (2009) also found that the use of e-filing is able to decrease one hour of time cost and monetary cost (direct costs) by 37 percent. Ibrahim (2014) also found that e-filing can reduce the time cost of $26 \%$ of the cost of time before e-filing is used on personal taxpayers in Malaysia.

Different test results conducted by Wilcoxon Signed-Ranks indicate that there are significant differences between the estimated cost of VAT compliance before and after e-invoicing. These findings are also consistent with the results of the research from Mansor et al (2009) who stated that using t-test different test, tax compliance costs in the form of the time cost and monetary cost before e-filing have significant 
differences in the compliance costs after e-filing is used. The tax compliance costs after the e-invoice has increased, although only 3.4 percent of the tax compliance costs before the e-invoice.

The increase occurred due to the direct costs incurred as a result of the registration procedure and the time cost spent for understanding the e-invoice either independently or by seeking help from the tax officials of Account Representative (AR) is greater than the decrease in the direct costs and time costs due to the use of e-invoice. This finding is supported by Ibrahim (2014), the use of e-filing increases the time cost for consulting (help-time) four times greater than in the manual reporting. Furthermore, the results of Signed Rand Wilcoxon different test indicate that there are no significant differences in the tax compliance costs six months before and after the e-invoices. Ibrahim (2014) also found that there is no statistical significant difference between the tax compliance costs before and after the use of e-filing with different test of MannWhitney $U$ test.

The confomrity of this results with the institutional change theory is creating an e-invoice is aimed to reduce tax compliance costs and optimize VAT receipts. The Implementation of e-invoicing is not removing to reporting VAT collection procedures, but only lowering the tax compliance cost by eliminating direct costs, such as the cost of buying or print the blank invoice taxes and lowering the cost of time either the time to make a tax invoice and filling SPT. However, the implementation from this study are e-invoicing can indirectly lowering the cost of tax compliance, compliance costs would rise temporarily because taxpayer need to charge more to adapt. After the taxpayer is able to adapt, accompanied by improved e-invoicing system itself, the cost of compliance will decrease.

\section{CONCLUSION}

The description of procedures of collection, calculation, deposit, and reporting of VAT before and after the e-invoice shows that e-invoice is not cutting or missing any activity. E-invoice is only shortening the time in the activity for invoicing and filling the tax notification letter (SPT). E-invoices can lower the estimation of VAT compliance costs within one year amounted to 31 percent of the compliance costs without e-invoice. Different test results conducted by Wilcoxon Signed-Ranks indicate 
Transaction Cost on The Implementation....

Clara Palupi, Darwanto

that there are significant differences between the estimation of VAT compliance cost before and after e-invoice.

The calculation of compliance costs for the tax year 2015 shows that the use of e-invoice in six months before and six months after that do not fit with the theory that the institutional change is used to reduce the transaction costs. The implementation of e-invoices cannot directly reduce the tax compliance costs, because of e-invoice is a new program, so the taxpayers need the big time cost for the process of adjustment (to adapt). Not only the taxpayers, the e-invoice system still often encountering problems shows that the tax authorities are also still at the stage of adapting to the changes made itself, it takes time to be able to continue to enhance the e-invoice in order to be used by the taxpayers without any problems. After the taxpayers and the tax authorities are able to adapt, then e-invoice can actually lower the tax compliance costs.

\section{REFERENCE}

Creswell, J.W. (2009). Research Design Pendekatan Penelitian Kualitatif, Kuantitatif, dan Mixed. Yogyakarta: Pustaka Pelajar.

Direktorat Jenderal Pajak Kementrian Keuangan RI. (20I2). Lampiran Keputusan Direktur Jenderal Pajak No KEP-334/PJ/20I2 tentang Rencana Strategis Direktorat Jenderal Pajak Tahun 20/2-20/4:10. Accessed in 12 December 2015 from www.ketentuan.pajak.go.id

Eragbhe, E. \& K.P Modugu. (20I4). Tax Compliance Costs of Small and Medium Scale Enterprises in Nigeria. International Journal of Accounting and Taxation. Vol. 2 (I): 63-87.

Evans, C. et.al. (2013). Tax Compliance Costs For the Small and Medium Enterprise Business Sector: Recent Evidence from Australia. Tax Administration Research Centre University of EXETER Discussion Paper: 003-I3.

Gumiwang, R. (20/4). Rasio Pungutan Pajak Masih Rendah. in online article of Financial Bisnis.com. Accessed in 8 August 2015, from www.financial.bisnis.com

Hansford, A. \& J. Hasseldine. (20I2). Tax compliance costs for small and medium sized enterprises: the case of the UK. ejournal of Tax Research of 
Taxation and Business Law (Atax). Vol. 10 (2): 288 - 303.

Ibrahim, I. (2014). The Compliance Time Costs of Malaysian Personal Income Tax System: E-filers vs. Manual-filers. Procedia-Social and Behavioral Sciences. 164: 522527

Kiryanto. (2000). Analisis Pengaruh Penerapan Struktur Pengendalian Intern Terhadap Kepatuhan Wajib Pajak bada Dalam Memenuhi Kewajiban Pajak Penghasilannya. EKOBIS. Vol. I No. I: 4I-52.

Klun, M. (2009). Pre-filled Income Tax Returns: Reducing Compliance Costs for Personal Income Taxpayers in Slovenia. Financial Theory and Practice. Vol. 33(2): 219-233.

Mansor, N.H.A \& M.M. Hanefah. (2008). Tax compliance costs of Bumiputera small and medium enterprises in Northern Malaysia. International Journal of Mangement Sciences. Vol. 15 (I): 21 -42.

Mansor, N.H.A. et.al. (2009). The Tax Compliance Costs of Individual Taxpayers: a Comparative Study on Manual Filing and Electronic Filing in Malaysia. Research Reports. Institute of Research, Development and Commercialization, Universiti Teknologi MARA, Malaysia.

OECD. (2004). Compliance Risk Management: Managing and Improving Tax Compliance. Centre for Tax policy and administration, Committee on Fiscal Affairs, h.35-45.

Prasetyo, A. (2008). Biaya Transaksi Dalam Perhitungan Pajak. Article accessed in 15 July 2015 from http://directory.umm.ac.id

Rao, P.K. 2003. The Economics of Transaction Costs: Theory, Methods and Applications. New Jersey: Palgrave Macmillan.

Rosdiana, H. \& R. Tarigan. (2005). Perpajakan Teori dan Aplikasi. Jakarta: RajaGrafindo Persada.

Sapiei, N.S. et.al. (20I4). Regressivity of the corporate taxpayers' compliance costs. Procedia-Social and Behavioral Sciences 164: 26-3I.

Smulders, S. \& M. Stiglingh. (2008). Annual Tax Compliance Costs for Small Businesses: a Survey of Tax Practitioners in South Africa. South African Journal of Economic and Management Sciences. Vol. II(3): 354371. 
Transaction Cost on The Implementation....

Clara Palupi, Darwanto

Susila, B. \& J. Pope. (20/2). The tax compliance costs of large corporate taxpayers in Indonesia. Australian Tax Forum. Vol. 27. No. 4: 719-730.

Yustika, A. E. (20I3). Ekonomi Kelembagaan: Definisi, Teori, dan Strategi. Jakarta: Penerbit Erlangga. 